\title{
Kompetensi Pejabat Struktural pada Badan Kepegawaian dan Pengembangan Sumber Daya Manusia Kabupaten Minahasa
}

\author{
$1^{\text {st }}$ Jeane E. Langkai \\ FIS UNIMA \\ Prodi ilmu administrasi negara \\ Tondano, Indonesia \\ jeanelangkai59@gmail.com \\ $2^{\text {nd }}$ Jetty E.H. Mokat \\ FIS UNIMA \\ Prodi ilmu administrasi negara \\ Tondano, Indonesia \\ jettymokat@unima.ac.id \\ $3^{\text {rd }}$ Vidi Kapahang \\ FIS UNIMA \\ Prodi ilmu administrasi negara \\ Tondano, Indonesia \\ vidikapahang@gmail.com
}

Abstrak - Penelitian ini bertujuan untuk mendeskripsi dan menganalisis kompetensi pejabat struktural pada BKPSDM Kabupaten Minahasa. Metode yang digunakan adalah kualitatif deskriptif dengan teknik pengumpulan data melalui observasi, teknik wawancara, dan dokumentasi. Hasil penelitian menunjukkan bahwa: 1). Terdapat pejabat struktural di BKPSDM memiliki keahlian yang belum sesuai dengan jabatan struktural yang dipercayakan kepada pejabat struktural di BKPSDM karena belum semuanya memahami Undang-Undang Aparatur Sipil Negara dan Peraturan tentang Manajemen PNS serta belum menyusun daftar kompetensi PNS sesuai PERMENPANRB No.38 Tahun 2017 tentang Standar Kompetensi Jabatan Aparatur Sipil Negara, 2). Terdapat pejabat struktural eselon III dan IV yang belum mengikuti diklat PIM III dan IV, 3). Pejabat struktural di BKPSDM memiliki kompetensi sosial kultural. Untuk itu disarankan: 1). Sebaiknya pejabat struktural di BKPSDM memiliki kompetensi teknis, sesuai dengan jabatan struktural yang dipercayakan kepada Pejabat struktural di BKPSDM serta sebaiknya memahami Undang-Undang Aparatur Sipil Negara dan Peraturan tentang Manajemen PNS serta sebaiknya disusun daftar kompetensi PNS sesuai PERMENPANRB No.38 Tahun 2017 tentang Standar Kompetensi Jabatan Aparatur Sipil Negara, 2). Sebaiknya Pejabat struktural eselon III dan IV mengikuti diklat PIM III dan IV, 3). Sebaiknya pejabat struktural di BKPSDM Kabupaten Minahasa memiliki kompetensi sosial kultural.

Kata kunci : Kompetensi Pejabat Struktural, BKPSDM Minahasa 


\section{PENDAHULUAN}

Peraturan Nomor 11 Tahun 2017 Tentang Manajemen PNS menetapkan tiga kompetensi yakni: a). Kompetensi Teknis, b). Kompetensi Manajerial, dan c). Kompetensi Sosial Kultural yang merupakan persyaratan yang harus dimiliki oleh pejabat structural [7].

Pejabat Struktural di Badan Kepegawaian dan Pengembangan Sumber Daya Manusia (BKPSDM) Kabupaten Minahasa untuk eselon III dan eselon IV ditemukan bahwa kompetensinya belum sesuai dengan ketentuan Peraturan Nomor 11 Tahun 2017 Tentang Manajemen PNS dimana terdapat sebagian dari pejabat struktural yang duduk dalam Jabatan struktural eselon III setara dengan Jabatan administrasi dan Jabatan struktural eselon IV setara dengan jabatan adminitrasi pengawas yang dalam hal ini Kepala Bidang dan Kepala Sub Bidang di BKPSDM berijasah Sarjana (S1) [7]. Selanjutnya jika dilihat dari indikator ijasah, terdapat beberapa jabatan struktural yang ditempati belum berdasar pada kompetensi keilmuan dan jabatan struktural di BKPSDM yang ditempati. Untuk itu dilakukan penelitian tentang kompetensi pejabat struktural di BKPSDM Kabupaten Minahasa

\section{Tujuan Penelitian}

Penelitian ini dilakukan untuk mendeskripsi dan menganalisis kompetensi pejabat struktural pada Badan Kepegawaian dan
Pengembangan Sumber Daya Manusia Kabupaten Minahasa.

\section{METODE PENELITIAN}

Tempat penelitian dilakukan di BKPSDM Kabupaten Minahasa, Provinsi Sulawesi Utara. Penelitian ini, menggunakan pendekatan kualitatif deskriptif dengan menfokuskan pada kompetensi pejabat struktural dalam hal Teknis yaitu pengetahuan, keterampilan, dan sikap/perilaku yang dapat diamati, diukur, dan dikembangkan yang spesifik berkaitan dengan bidang teknis Jabatan. Kompetensi Manajerial yaitu pengetahuan, keterampilan, dan sikap/perilaku yang dapat diamati, diukur, dikembangkan untuk memimpin dan/atau mengelola unit organisasi. pelatihan struktural atau manajemen, dan pengalaman kepemimpinan.

Kompetensi Sosial Kultural yaitu pengetahuan, keterampilan, dan pengalaman berinteraksi dengan masyarakat majemuk dalam hal agama, suku dan budaya, perilaku, wawasan kebangsaan, etika, nilai-nilai, moral, emosi dan prinsip, yang harus dipenuhi oleh setiap pemegang Jabatan untuk memperoleh hasil kerja sesuai dengan peran, fungsi dan Jabatan. Kompetensi Sosial Kultural diukur dari pengalaman kerja berkaitan dengan masyarakat majemuk dalam hal agama, suku, dan budaya sehingga memiliki wawasan kebangsaan.

Data yang digunakan adalah data primer dan sekunder. Data primer diperoleh dari informan yaitu: PNS yang mendapat pembinaan, PNS yang akan mengikuti pelatihan, serta PNS 
yang akan pensiun. Selanjutnya dilakukan klarifikasi kepada: Kasubid Hukum, Kasubag Umum dan Perlengkapan, Kasubag Program Keuangan dan Pelaporan, Kasubid Pensiun Pegawai, Kasubid Informasi Kepegawaian, Kasubid Diklat, Kabid Pembinaan Pegawai dan Kabid Pengembangan Sumber Daya Manusia.

Data dianalisis secara deskriptif kualitatif.

\section{HASIL DAN PEMBAHASAN}

Kompetensi pegawai sangat menentukan hasil pekerjaan yang dikerjakan. Setiap PNS di wajibkan untuk memiliki kompetensi, terlebih lagi jika PNS tersebut berada dalam jabatan Struktural dalam suatu organisasi. Pejabat Struktural yang ada haruslah memenuhi kompetensi jabatan seperti kompetensi teknis, kompetensi manajerial, serta kompetensi sosial kultural untuk menyelesaikan pekerjaan demi tercapainya tujuan organisisi secara efisien dan efektif di bidang kepegawaian. Akan tetapi, bagaimana jika PNS yang telah duduk dalam jabatan Struktural tapi kompetensinya tidak sesuai dengan bidangnya atau sesuai dengan bidangnya tetapi belum menguasai bidangnya.

Persoalan tersebut sering kali muncul di setiap lingkungan instansi publik, termasuk di kantor Badan Kepegawaian dan Pengembangan Sumber Daya Manusia (BKPSDM) Kabupaten Minahasa. Untuk mengetahui Kompetensi dari pegawai dalam jabatan struktural di BKPSDM Kabupaten Minahasa, yang menjadi landasan hukum peneliti yaitu berdasarkan PP Nomor 11 Tahun 2017 Tentang Manajemen PNS, dijelaskan dalam peraturan tersebut bahwa PNS haruslah memenuhi dan memiliki kompetensi diantaranya: 1) Kompetensi Teknis, 2) Kompetensi Manajerial, dan 3)Kompetensi Sosial/Kultural. Ketiga kompetensi tersebut yang akan menjadi fokus deskripsi dari penelitiKetiga kompetensi tersebut merupakan salah satu syarat yang wajib di penuhi dan dimiliki dalam menduduki suatu jabatan tertentu yang sesuai dengan standar kompetensi yang telah disusun dan ditetapkan [7].

\section{1) Kompetensi Teknis}

Terdapat temuan yang di dapat terkait kompetensi teknis pejabat struktural di BKPSDM diantaranya : Pejabat struktural di BKPSDM menunjukkan tingkat pendidikan minimal S1 dengan spesialisasi pendidikan yang berbeda. Pejabat struktural di BKPSDM memiliki kompetensi teknis, tetapi terdapat ijasah S1 atau keahlian yang belum sesuai dengan jabatan struktural yang dipercayakan. Pejabat struktural mengalami kesulitan saat mendapat tugas yang baru, tapi dapat di atasi dengan meminta bantuan kepada pimpinan dan rekan kerja. Pejabat dalam jabatan struktural di BKPSDM kurang mengetahui dan menguasai regulasi dalam hal ini yaitu UU No.5 Tahun 2014 tentang ASN dan PP No.11 Tahun 2017 tentang Manajemen PNS [9].

\section{2) Kompetensi Manajerial}

Terdapat temuan yaitu pejabat struktural memiliki kompetensi manajerial dalam memimpin pegawai. Pejabat struktural mengalami kesulitan saat mendapat pekerjaan yang baru, tapi dengan 
meminta bantuan kepada pimpinan dan rekan kerja.

Pendidikan dan pelatihan pejabat struktural belum semuanya mengikuti diklat PIM IV untuk eselon IV sebelum menduduki jabatan struktural begitu pula dalam eselon III belum semuanya yang mengikuti diklat PIM III. Dalam pelaksanaan Diklat terdapat kendala dari Anggaran Daerah yang kurang mencukupi dan juga Kurangnya antusias dan kesiapan dari para PNS atau Pejabat Struktural yang akan mengikuti pendidikan dan Diklat untuk meningkatkan kompetensi.

\section{3) Kompetensi Sosial Kultural}

Pegawai dalam jabatan struktural sudah memiliki kompetensi sosial kultural di ukur dengan pengalaman kerja di masyarakat majemuk dalam hal agama, sosial dan budaya. Pegawai dalam jabatan struktural merupakan masyarakat yang aktif dalam organisasi kemasyarakatan dan agama.

Peraturan Pemerintah Nomor 100 Tahun 2000 tentang Pengangkatan PNS Dalam jabatan Struktural menjelaskan mengenai persyaratan untuk dapat diangkat dalam jabatan struktural yang di antaranya memiliki kompetensi jabatan yang di perlukan dan memiliki kualifikasi dan tingkat pendidikan yang telah ditentukan [5]. Selain beberapa persyaratan itu Pejabat Pembina Kepegawaian Pusat dan Pejabat pembina Kepegawaian Daerah perlu memperhatikan faktor senioritas dalam kepangkatan, usia, pendidikan dan pelatihan jabatan, dan pengalaman yang dimiliki.

Lebih lanjut dalam Peraturan Pemerintah Nomor 13 tahun 2002 tentang perubahan atas Peraturan Pemerintah Nomor 100 tahun 2000 tentang Pengangkatan Pegawai Negeri Sipil Dalam Jabatan Struktural pada Pasal 7 ayat (1) menjelaskan bahwa Pegawai yang akan atau telah menduduki jabatan struktural harus mengikuti dan lulus pendidikan dan pelatihan kepemimpinan (PIM) sesuai dengan kompetensi yang ditetapkan untuk jabatan tersebut [6].

Bila mengacu pada Peraturan Menteri Pendayagunaan Aparatur Negara dan Reformasi Birokrasi (PERMENPANRB) Nomor 38 Tahun 2017 tentang Standar Kompetensi Jabatan Aparatur Sipil Negara menyebutkan bahwa Standar kompetensi Jabatan ASN merupakan deskripsi pengetahuan, keterampilan dan perilaku yang diperlukan seorang Aparatur Sipil Negara dalam melaksanakan tugas jabatan. Secara ideal yang diharapkan, para pegawai yang ada khususnya pegawai dalam jabatan struktural mampu memiliki tiga kompetensi yaitu kompetensi teknis, kompetensi manajerial, dan kompetensi sosial kultural dalam menjalankan tugasnya [4].

Mengacu pada pendapat Stephen J. Kenezevich (1984:17) yang menjelaskan bahwa kompetensi adalah kemampuan-kemampuan untuk mencapai tujuan organisasi. Maka dapat simpulkan bahwa kemampuan-kemampuan ataupun keterampilan-keterampilan yang di miliki 
oleh seorang pegawai sangat menentukan tercapainya tujuan dari organisasi. Jika tidak memiliki kompetensi, maka akan terdapat kesulitan untuk mencapai tujuan organisasi.

Sementara menurut pendapat yang di kemukakan oleh Mitrani A. (1995:21), bahwa Kompetensi adalah suatu sifat dasar seseorang yang dengan sendirinya berkaitan dengan pelaksanaan suatu pekerjaan secara efektif atau sangat berhasil. Untuk itu dengan adanya kompetensi pegawai maka yang merupakan kemampuan dasar yang di miliki oleh pegawai untuk mengerjakan tugas dan dapat membantu organisasi mencapai tujuan dengan efektif [1].

Dari proses wawancara peneliti menanyakan tentang kompetensi-kompetensi yang di miliki oleh setiap pegawai yang duduk dalam jabatan struktural, selain itu peneliti juga menanyakan faktor apa yang menyebabkan kompetensi atau kemampuan dari seorang pegawai struktural tidak berkembang, pimpinan BKPSDM beranggapan bahwa hal menyebabkan kompetensi pegawai itu tidak berkembang dilihat dari data karena disebabkan oleh kurangnya diklat yang menyebabkan kompetensi tidak berkembang, jika pegawai ingin mengembangkan kompetensinya pasti berusaha untuk mencari informasi mengenai diklat, jadi kembali lagi kepada pribadi masing-masing. Untuk pelaksanaan diklat juga tergantung dari anggaran yang tersedia.

Berdasarkan hal yang terjadi di Badan Kepegawaian dan Pengembangan Sumber Daya
Manusia Kabupaten Minahasa soal pegawai dalam jabatan struktural yang memiliki kompetensi yang belum sesuai, pimpinan BKPSDM Kabupaten Minahasa beranggapan bahwa hal tersebut bukanlah kesalahan dari suatu sistem penempatan yang diberikan kepada pegawai tersebut. Para pegawai yang bekerja di sini kebanyakan memiliki keterampilan yang luas selain bidang yang mereka tempati, sehingga jika di tempatkan pada jabatan atau posisi yang kurang sesuai dengan kompetensi maka pegawai tersebut berusaha untuk tetap menyelesaikan tugasnya dengan mencari bantuan dan berkoordinasi dengan pimpinan BKPSDM yang ada.

Mendasari pernyataan diatas, maka dapat di simpulkan bahwa secara teknis pegawai dalam jabatan struktural yang memiliki kompetensi teknis yang sudah sesuai peraturan yang ada dimana pejabat struktural tersebut memiliki latar belakang pendidikan yang minimal S1. Pejabat struktural yang ada sudah memiliki pengetahuan, pelatihan fungsional dan juga spesialisasi pendidikan yang ada.

Akan tetapi, terdapat juga pejabat yang spesialisasi pendidikannya belum sesuai dengan bidang kerjanya. Itulah yang menjadi persoalan mengenai sumber daya dengan latar belakang pendidikan yang sesuai dengan bidang tugas yang ada di BKPSDM terkadang tidak sesuai dengan bidang tugas yang ada sehinggga langkah yang dilakukan oleh pemimpin BKPSDM Kabupaten Minahasa adalah menyesuaikan dengan apa yang ada. 
Dari uraian diatas dapat dipahami bahwa kompetensi yang di miliki oleh setiap pegawai dalam jabatan struktural di tentukan dengan kemampuan dan pengalaman kerja yang di miliki oleh pejabat yang terkait. Kemampuan pegawai di lihat dan di ukur dari tingkat pendidikannya yang sudah memenuhi prosedur pengangkatan aparatur yang ada, begitu juga dengan spesialisasi pendidikan yang di miliki oleh pejabat struktural yang ada sudah sesuai dengan bidang kerja yang ada. Dan jika tidak sesuai para pejabat struktural yang menyesuaikan dengan bidang kerja masingmasing. Jika di lihat dari pengalaman dan pelatihan PIM yang wajib diikuti para pejabat struktural yang ada di dapati belum semua yang mengikuti diklat PIM IV dan PIM III.

Mengacu pada pendapat yang di kemukakan oleh Heidrachman dan Husnan, Suad (2002) menyatakan bahwa latihan-latihan yang diberikan kepada para pegawai, juga sering mendorong para pegawai bekerja lebih keras. Berdasarkan pertanyaan tersebut dapat dipahami bahwa pelatihan untuk pegawai itu sangat penting untuk membantu pegawai mengerjakan tugasnya. Dengan adanya pelatihan kompetensi dari pegawai dapat meningkat sehingga pekerjaan yang di kerjakan akan terasa lebih ringan dan membuat pegawai lebih semangat dalam mengerjakan tugas secara efektif [2].

Kompetensi pegawai dalam jabatan struktural yang kurang menguasai bidang kerjanya yang menyebabkan kemampuan yang ada kurang berkembang karena tidak mengikuti pendidikan dan pelatihan sesuai dengan posisi jabatan yang diduduki. Sejalan dengan itu, seperti yang di kemukakan oleh Wasti Sumarno (1990:75) bahwa pendidikan merupakan proses belajar yang menghasilkan pengalaman yang memberikan kesejahteraan pribadi, baik lahiriah maupun batiniah. Sedangkan pelatihan adalah keseluruhan proses, teknik, dan metode belajar-mengajar dalam rangka mengalihkan sesuatu pengetahuan dari seseorang kepada orang lain sesuai dengan standar yang telah ditetapkan sebelumnya. Dapat di pahami bahwa dengan adanya Pendidikan dan Pelatihan oleh pejabat struktural dapat membantu organisasi mencapai tujuan yang telah di tentukan sebelumnya [8].

Para pejabat struktural yang memiliki kompetensi yang kurang sesuai dengan bidang kerjanya di sebabkan karena peraturan dari pemerintah pusat yang sering berubah-ubah, sehingga pemerintah daerah dalam hal ini BKPSDM Kabupaten Minahasa harus menyesuaikan dengan perubahan peraturan tersebut. Pejabat struktural yang mendapat kesulitan atas peraturan tersebut meminta bantuan kepada rekan kerja dan juga staf yang untuk membantu pekerjaan menjadi efektif. Sejalan dengan itu karena harus menyesuaikan dengan reformasi birokrasi yang sehingga pegawai struktural wajib meningkatkan kompetensinya agar tidak tertinggal dengan perkembangan zaman yang semakin berbasis informasi komunikasi dan teknologi atau era digital. Untuk itu para pejabat struktural perlu mengikuti kegiatam-kegiatan 
untuk meningkatkan kompetensi seperti mengikuti pendidikan dan diklat sesuai dengan jabatan dan pangkat yang diduduki dan juga dapat mengikuti berbagai seminar, sosialisasi hingga workshop-workshop yang berkaitan dengan bidang kerja para pejabat struktural yang ada di BKPSDM Kabupaten Minahasa.

Para pejabat struktural di BKPSDM Kabupaten Minahasa yang ingin meningkatkan kompetensi sering kali juga dihadapkan dengan berbagai tantangan dan kendala misalnya berupa anggaran atau dana yang tersedia kurang memadai dan cukup untuk melakasanakan pendidikan dan pelatihan pegawai tersebut. Disamping juga anggaran daerah yang belum mencukupi, kendala lain juga yaitu karena terdapat pemahaman dari pegawai yang akan mengikuti diklat bahwa mengikuti diklat dan tidak itu sama saja. Karena pemahaman yang salah tersebut sehingga kurangnya antusias dari para pejabat struktural yang ingin meningkatkan kompetensi yang mereka miliki.

\section{PENUTUP}

\section{Kesimpulan}

Berdasarkan hasil penelitian, maka dapat ditarik kesimpulan berikut:

1. Terdapat pejabat struktural di BKPSDM memiliki keahlian yang belum sesuai dengan jabatan struktural yang dipercayakan kepada pejabat struktural di BKPSDM karena belum semuanya memahami Undang-Undang Aparatur Sipil Negara dan Peraturan tentang
Manajemen PNS serta belum menyusun daftar kompetensi PNS sesuai PERMENPANRB No.38 Tahun 2017 tentang Standar Kompetensi Jabatan Aparatur Sipil Negara.

2. Terdapat pejabat struktural eselon III dan IV yang belum mengikuti diklat PIM III dan IV.

3. Pejabat struktural di BKPSDM memiliki kompetensi sosial kultural.

\section{Saran}

Dalam penetapan jabatan struktural pada BKPSDM disarankan:

1. Sebaiknya pejabat struktural di BKPSDM memiliki kompetensi teknis, sesuai dengan jabatan struktural yang dipercayakan kepada Pejabat struktural di BKPSDM serta sebaiknya memahami UndangUndang Aparatur Sipil Negara dan Peraturan tentang Manajemen PNS serta sebaiknya disusun daftar kompetensi PNS sesuai PERMENPANRB No.38 Tahun 2017 tentang Standar Kompetensi Jabatan Aparatur Sipil Negara.

2. Sebaiknya Pejabat struktural eselon III dan IV mengikuti diklat PIM III dan IV.

Sebaiknya pejabat struktural di BKPSDM Kabupaten Minahasa memiliki kompetensi sosial kultural. 
Terimakasih disampaikan kepada semua pihak yang boleh membanti dalam pelaksaan penelitian sehingga artikel ini dapat diselesaikan.

\section{REFERENSI}

[1] Alain, Mitrani. 1995. Manajemen Sumber Daya Manusia Berbasis Kompetensi (terjemahan). Jakarta: PT. Intermasa.

[2] Heidrachman dan Husnan, Suad. 2002. Manajemen Personalia. Yogyakarta: BPFE.

[3] Kenezevich, Stephen J. 1984. Administration of Public Education. New York: Harper Collins Publishers.

[4] Peraturan Menteri Pendayagunaan Aparatur Negara dan Reformasi Birokrasi Nomor 38 Tahun 2017 tentang Standar Kompetensi Jabatan Aparatur Sipil Negara.

[5] Peraturan Pemerintah Nomor 100 Tahun 2000 Tentang Pengangkatan Pegawai Negeri Sipil Dalam Jabatan Struktural.

[6] Peraturan Pemerintah Nomor 13 Tahun 2002 Tentang Perubahan Atas Peraturan Pemerintah Nomor 100 Tahun $2000 \quad$ Tentang Pengangkatan Pegawai Negeri Sipil Dalam Jabatan Struktural.

[7] Peraturan Pemerintah Nomor 11 Tahun 2017 Tentang Manajemen Pegawai Negeri Sipil.

[8] Sumarno, Wasti. 1990. Manajemen Sumber Daya Manusia. Jakarta: Mandar Maju.

[9] Undang-Undang Nomor 5 Tahun 2014 tentang Aparatur Sipil Negara (A.S.N). 